DOI: $10.17516 / 1997-1370-0359$

УДК 342.25

\title{
Constitutional and Legal Development of the Republic of Sakha (Yakutia) in the Post-Soviet Period
}

\author{
Albina A. Stepanova, Afanasy I. Stepanov \\ and Sofia S. Alekseeva* \\ M.K. Ammosov North-Eastern Federal University \\ Yakutsk, Russian Federation
}

Received 14.10.2018, received in revised form 11.12.2018, accepted 20.12.2018

\begin{abstract}
Modern tendencies of the Russian federalism development, as well as their impact on the constitutional and legal development of the Republic of Sakha (Yakutia) as a federal subject are observed and analyzed in the article. Changes introduced into the Republic's constitutional legislation are characterized in detail. The aim of the study is to determine the degree of influence of the federal center on the constitutional and legal development of the Republic. Historical, technical and legal, and comparative legal methods have been used in the study. Two stages of contemporary constitutional and legal development of the Republic are distinguished in the article: from 1990 to 2000, and from 2000 to the present day. The first stage is characterized by a relative freedom granted to the Republic when forming its constitutional space, including its national and territorial organization. Meanwhile, the next stage is marked by consistent and almost complete limitation of its constitutional and legal sovereignty. A rather pronounced federal interference into constitutional and legal space of the federal subjects, limiting their freedom in defining the mechanisms of interaction between national governing bodies and establishing their own national and legal institutions, could be observed in today's Russia. The authors of the article believe that such interference impacts the Republic's constitutional and legal progress in a negative way, and contemporary Russia needs, at least, to introduce a form of federal government self-limitation when it comes to federal relations and, hence, optimization of constitutional mechanisms which separate federal and regional interests.
\end{abstract}

Keywords: republic, constitution, federalism, sovereignty, constitutional amendment, federal intervention.

Research area: culturology.

(C) Siberian Federal University. All rights reserved

* Corresponding author E-mail address: aastepanova@mail.ru; Afanasystepanov@gmail.com; aleksofa@mail.ru 
Citation: Stepanova, A.A, Stepanov, F.I., Alekseeva, S.S. (2018). Constitutional and legal development of the Republic of Sakha (Yakutia) in the post-Soviet period. J. Sib. Fed. Univ. Humanit. Soc. Sci., 15(4), 467-475. DOI: 10.17516/1997-1370-0359.

\section{Introduction}

During the period of social and political reforms in the early $1990 \mathrm{~s}$, almost all former autonomous republics declared their state sovereignty following Russia's adoption of "The Declaration of State Sovereignty of the Russian SFSR" on June 12, 1990․ Declaring themselves as sovereign states, the autonomous republics supposed firstly, that "the status of autonomous republic limits their sovereign rights, does not correspond to the fundamental principles of the constitutional state, and slows down social and economic development" (Preamble of the "Declaration on State Sovereignty of the Yakut-Sakha SSR"). Indeed, even with a constitutional basis, an autonomous republic, in fact, was a political, rather than a constitutional entity.

The state structure of an autonomous republic was fully determined by the central authorities. According to article 78 of the Constitution of the RSFSR of 1978, outside the USSR and RSFSR jurisdiction an autonomous republic could make decisions within its own jurisdiction. However, provisions of Article 72 which stated the jurisdiction of the RSFSR prevented the autonomous republics from not only making decisions concerning their own budget, but even those in the sphere of utility services, and provision of urban amenities.

Therefore, the reason why the republics strived to advance their state and legal status and reject "autonomous" characteristics was understandable.

Secondly, complete dependence, including economic one, on the central government when solving any production and commercial issues was also the factor that urged the republics to search for ways of improving their statehood. In particular, even though the Republic of Yakutia was the major supplier of raw materials,

\footnotetext{
For instance: June $20^{\text {th }}, 1990$ - the North Ossetian ASSR; August $9^{\text {th }}, 1990$ - the Karelian ASSR; August 29 ${ }^{\text {th }}, 1990$ - the Komi ASSR; September $27^{\text {th }}, 1990$ - the Yakut-Sakha SSR, etc.
}

it was the last in terms of infrastructure indicators.

Thirdly, such an important factor as growing national identity of the indigenous population of the republics cannot be ignored. It is a well-known fact that both the RSFSR and the USSR were the so-called ethnic federations (Farukhshin, 2017). When giving critical assessment of such an approach to a federative state formation, it is worth noting that this approach has always been an attempt to find solution to the ethnic problem. Therefore, their self-recognition as independent nation-forming ethnic groups has largely contributed to the sovereignty declaration by the republics. Due to this fact, the federal center later blamed the republics of separatism and proclaimed their declarations inconsistent with the Federal Constitution.

The Declaration on State Sovereignty proclaimed the Republic of Yakutia a sovereign state based on the expression of will of the people (Article 1). The population consisting of people of all nationalities was recognized as the supreme bearer of sovereignty. The Declaration also formalized: full authority of the Republic when making decisions in the spheres of national and public interests with the exception of those voluntarily delegated under the jurisdiction of the USSR and RSFSR (Part 4, Article 1), voluntary and equal union of the Republic with other subjects of the RSFSR and the USSR based on the Federal and Union agreements (Part 3, Article 1), and fundamentals of the Republic's economic system (Article 5), etc. The supremacy of the Constitution and laws of the Republic in its territory was established to ensure sovereignty, but, at the same time, it was stated that the laws of the USSR and the RSFSR that were adopted within the scope of their powers and voluntarily delegated to their jurisdiction are of supreme legal priority in the territory of the Republic (Article 2).

Along with this, it should be noted that the Declaration is a political document. Its adop- 
tion is usually determined by specific political circumstances. Its provisions, as a rule, must be legitimized, as it is stated in the Declaration: "the present Declaration is the basis for developing the new Constitution of the Yakut Sakha SSR..." (Article 11).

The Constitution of the Republic of Sakha (Yakutia) adopted in April 1992 completed the initial stage of constitutional and legal formalization of the Republic's statehood. It declared the Republic a sovereign, democratic, and constitutional state, based on the people's right of self-determination. The latter, at the same time, was interpreted as the people's right to choose their path of development, the right to their statehood and independence of decision-making in the sphere of internal affairs.

It is obvious that new realities of public life and the complexity of challenges the Republic faced - formation of statehood, creating effective economy and civil society formation - called for reforms of the Republic governance mechanisms. The former state authority mechanism proved to be ineffective in solving the new set of problems.

\section{Reforms of 1990-1993}

The elections to the Supreme Council of the Republic which took place in spring 1990 became the first step on the way to re-organization of the old state institutes which no longer corresponded to the new environment. These were the first elections conducted on the alternative basis: 663 candidates were nominated for 165 council seats (according to the Constitution of the Yakut Autonomous SSR of 1978). The Supreme Council exercised its powers till October 1993. During three years of its operation the Constitution of the Republic (on October $\left.16^{\text {th }}, 1992\right)$, the Act on the Election of the President of the Republic (October 16 $\left.{ }^{\text {th }}, 1991\right)$, the Constitutional Court Act (February $7^{\text {th }}, 1992$ ), as well as many other acts were adopted.

The next step in the process of reorganizing the state and legislative institutions was establishing the post of the President of the Republic. The reasons for the post establishment were common to the USSR, former Soviet republics and Russian republics: fundamental changes in the political system determined by the elimination of one-party system in the political sphere and, primarily, in the country governance; objective inability of the representative bodies to react to the changing situation; lack of efficiency of the collegial bodies; the need for the leadership capable of uniting positive social and political forces, movements, etc. Besides, such subjective factors as personal aspirations of the republican leaders to solidify their own status cannot be ignored.

Thirdly, the Constitutional Court of the Republic was established. The Act on the Constitutional Court of the Republic of Sakha (Yakutia) of February $7^{\text {th }}, 1992$ became the legal basis of the Court's activity. Over the period of the draft act elaboration many spoke up against this body establishment. Some believed that constitutional control could only be implemented at the federal level. Others stated that "the body of law of the republican level is not big enough to cause any conflicts between the legislative and executive branches" (Mironov, 1994). Nevertheless, the Constitutional Court was established and provision of the supremacy of the republican Constitution, and exercising constitutional control were stated as its main functions.

Thus, by 1993 the system of the higher bodies of the state authority in the Republic of Sakha (Yakutia) was mainly formed. However, the political and social situation formed in the Russian Federation in September and October 1993 pre-determined the further course of reforms for the state and legal institutions in both the Federation and the Republic.

According to the well-known Decree of the President of the Russian Federation No.1400 of September 21 ${ }^{\text {st }}, 1993$, the work of the Councils of all levels was suspended. After some hesitation on October $12^{\text {th }}, 1993$, the Supreme Council of the Republic of Sakha (Yakutia) adopted the resolution entitled "On the Reformation of the Representative Power Bodies in the Republic of Sakha (Yakutia)", according to which its work was officially suspended. The same resolution also suspended the work of the Constitutional Court of the Republic. The date of the elections to the new parliament of the Republic was set on December $12^{\text {th }}, 1993$, and it was determined that until the corresponding amend- 
ments to the Constitution are introduced, it would be the President of the Republic who will approve the Provisions concerning both parliament and parliamentary elections. Until the new parliament starts operating (Article 8 of the Resolution), the Supreme Council conferred authority to provide legal regulation of the issues concerning budget, taxation, pricing policy, and social sphere to the President. Thus, the Supreme Council to some extent legitimized the following acts of the President, who published decrees in the above-mentioned spheres in accordance with the authority conferred to him. In this regard it can be affirmed that serious violations of constitutional legitimacy were prevented when reorganizing the state government agencies. Reservations about the legality of such a delegation are, of course, reasonable, but under conditions of the legislative body self-dissolution (that was not provided by the legislation at that period), it seems that empowering the President with the corresponding authority by the legislative body was if not particularly well-grounded, but a necessary act.

Activity on the new Parliament formation started immediately. In October 1993 the President of the Republic signed the Decree on the Legislative Assembly (Il Tumen) of the Republic of Sakha (Yakutia), and the Decree on the elections to it. The first composition of the Parliament was elected on December $12^{\text {th }}$, 1993. "Provision on the Legislative Assembly (Il Tumen ${ }^{2}$ )" of October $30^{\text {th }}, 1993$ provided the establishment of two-chamber parliament with the Lower Chamber representing the whole republic, and the Upper one representing the interests of the uluses (regions of the Republic) and towns of republican subordination. The Lower Chamber (the House of Representatives) was represented by 21 deputies $^{3}$ (representatives), while the Upper Chamber (the House of the Republic) hosted 35 deputies according to the number of uluses and towns of republican

\footnotetext{
2 According to the Institute of Language, Literature, and History of the Republic of Sakha (Yakutia) (see: Sovety Yakutii of October $13^{\text {th }}, 1993$ ) the meaning of the word-combination "Il Tumen" could be defined as "a state body making decisions which are mandatory for all, in peace and agreement".

3 Later, the number of deputies' seats reached 35, thus becoming equal with the number of seats in the Upper Chamber.
}

subordination. Therefore, when electing deputies to the Upper Chamber an electoral district was represented by a territory of a large administrative unit, while during the election to the Lower Chamber the territory of the Republic was divided into equal electoral districts regardless of the territorial borders between the uluses.

By the end of 1993 the state authority bodies system of the Republic was formed and was functioning with some minor changes till the early 2000 s.

\section{Contemporary state of constitutional and legal development of the Republic of Sakha (Yakutia)}

With the adoption of the Federal Law No. 184 entitled "On the General Principles of the Organization of the Legislative (Representative) and Executive Bodies of State Power of the Subjects of the Russian Federation" in 1999 and the well-known Resolution of the Constitutional Court of the Russian Federation of June $7^{\text {th }}, 2000$ the new stage of constitutional and legal development of the Republic began. Some researchers even refer to this stage as "the stage of returning to the unitarian statehood" (Umnova, 2013). Nearly the entire process of constitutional and legal development of the Republic is confined to bringing the republican Constitution in compliance with the federal legislation requirements. It is natural that the fact that "constitutional and legal framework of the Republic is within the federal structure of Russia" (Ilyina, 2015) pre-determines the processes of the legislation unification. A unified state cannot have conflicting understandings of the principles for the state authority organization and the ways of their implementation. Thus, on October $17^{\text {th }}, 2002$ additional supplements and amendments to the Constitution of the Republic were adopted. They brought the constitutional basis of the Republic, as well as constitutional and legal status of the President of the Republic, in accordance with the federal legislation. Parliamentary structure and the system regulating the relationship between legislative and executive branches were reorganized as well. In 2008 another two Constitutional Laws of the Republic of Sakha (Yakutia) entitled "On 
Introduction of Amendments and Supplements to the Constitution of the Republic of Sakha (Yakutia)" were adopted. It is worth noting that to provide the supremacy of federal legislation Russia implements all measures of legislative influence on the subjects of the Federation. In September 2008 the Prosecutor of the Republic of Sakha (Yakutia) protested against several norms of the Constitution (Fundamental Law) of the Republic of Sakha (Yakutia). In brief, the Prosecutor Office's complaints were focused on the failure to bring certain norms of the Constitution (Fundamental Law) of the Republic of Sakha (Yakutia), particularly those dealing with the sovereignty of the Republic, into conformity with federal legislation. Following the inquiry from the State Assembly (Il Tumen) of the Republic of Sakha (Yakutia), the Constitutional Court of the Republic gave interpretations to certain provisions of the Constitution (Fundamental Law) of the Republic of Sakha (Yakutia) which establish sovereignty of the Republic. It should be noted that the Constitutional Court of the Republic of Sakha (Yakutia) cannot give legal assessment to the Constitution of the Republic and make statements about compliance or noncompliance of the Constitution of the Republic with federal legislation or the Constitution of the Russian Federation. As the body that protects the Constitution of the Republic, the Constitutional Court of the Republic of Sakha (Yakutia) may only give official interpretation of the meaning of constitutional norms. Therefore, the Resolution of the Constitutional Court of the Republic of Sakha (Yakutia) of February $18^{\text {th }}, 2009$ may only be considered taking into account the aforementioned circumstances. Thus, the Resolution of the Constitutional Court of the Republic of Sakha (Yakutia) indicates that "the provision of the preamble to the Constitution (Fundamental Law) of the Republic of Sakha (Yakutia) stating that the Constitution is adopted on the basis of the Declaration on State Sovereignty of the Republic reflects the priority of the Declaration in the process of Yakutia's transition from the Yakut Autonomous Soviet Socialist Republic to the new status of "the republic within the Russian Federation". Indeed, the goals of the constitution, indicating the historical condi- tions for its adoption are usually stated in the Preambles. This part is important both politically and ideologically. The Constitution of the Republic of Sakha (Yakutia) was adopted in 1992, correspondingly, its Preamble reflects the historical conditions that determined its adoption. The people of the Republic adopted the Constitution during the period when the republics' statehood was actively developing and when the sovereignty of the republics was not denied (Federal Treaty of 1992), which was reflected in the Preamble.

Interpretation of the meaning of the Constitutional norm (Fundamental Law) of the Republic of Sakha (Yakutia) in the sense that "as a measure of its independence in ensuring its economic, social and cultural development and possession of all the powers of government outside the Russian Federation jurisdiction and authority of the Russian Federation and the Republic of Sakha (Yakutia), does not endow the Republic with the properties of a sovereign state, it is not aimed at limiting the state sovereignty of the Russian Federation, does not breech the norms of constitutional equality of other subjects of the Russian Federation, but reflects the right of the people of the Republic to self-determination and the freedom of will when choosing a form of statehood; it expresses the Republic's right to advance its statehood and to exercise state authority independently" is also provided within the framework of the above-mentioned powers of the Constitutional Court of the Republic.

Sovereignty is a theoretical category. Therefore, much depends on which theory of sovereignty a state follows when organizing its structure. State sovereignty is a kind of an indicator of political development which introduces novelties determined by the needs of an era and the states into both the theoretical and practical aspects of sovereignty (Bredikhin, 2014; Pastukhova, 2010). There are two widely recognized sovereignty theories: a divisible sovereignty and indivisible sovereignty theory. The divisible (or "divided") sovereignty theory dwells on understanding of the federative power organization as a division of the aggregate authority. Accordingly, authority is divisible, as is sovereignty. Following the theory, there 
is no subordination of one state authority to another, but the distribution of competence in the territory of the federation; therefore, each of the subjects of authority acts in this territory as a sovereign, exercising its authority within its competence.

The theory of indivisible sovereignty, on the contrary, comes from the fact that sovereignty is the basis and the source of rights (authorities), but cannot act as those rights. The theory strongly opposes any kind of limitations imposed on the supreme power. According to this theory the authority cannot be sovereign and complete, provided that it is within even more sovereign authority. This is the theory the Russian Federation currently adheres to. According to the resolutions of the Constitutional Court of the Russian Federation "the sovereignty of the Russian Federation, as stated by the Constitution of the Russian Federation, excludes the existence of two levels of sovereign authorities that exercise supremacy and independence within a single system of state power; that is, it does not allow the sovereignty of the republics, or other subjects of the Russian Federation" (Resolution of June $7^{\text {th }}, 2000$, Definitions of June $27^{\text {th }} 2000$, April $19^{\text {th }}, 2001$, December $\left.6^{\text {th }}, 2001\right)$.

In June 2009, the Constitutional Law of the Republic of Sakha (Yakutia) was adopted. This Law was of crucial significance, since it introduced amendments and supplements to the norms of the Constitution of the Republic of Sakha (Yakutia) establishing the national status of the Republic.

Amendments were introduced to Paragraph 3 of the Preamble which previously contained provisions stating that the Constitution is adopted "based on the Declaration on State Sovereignty of the Republic". Amendments to the Preamble were made following the resolution of the Constitutional Court of the Russian Federation, which had previously recognized the provisions of the Constitution of the Republic of Bashkortostan as non-compliant with the Constitution of the Russian Federation. That is why the amended version of Paragraph 3 states: "TAKING into consideration incorporation of Yakutia into the Russian State in the $17^{\text {th }}$ century; establishment of the Yakut Autonomous So- viet Socialist Republic in 1922 as recognition of Yakutia's statehood; the republic's reformation in 1990 to the Yakut-Sakha Soviet Socialist Republic in accordance with the Declaration on State Sovereignty of the Republic, which in 1991 was re-named the Republic of Sakha (Yakutia) based on the resolution of the Supreme Council of the Yakut-Sakha Soviet Socialist Republic". It should be noted that the amended version of the Preamble retained the provisions which reflect the historical facts which had preceded the adoption of the Constitution of the Republic and laid the ground for the formation and consolidation of the Republic's statehood. It reflects both all the historical milestones of the Republic's development and social and political context which pre-determined the adoption of the Constitution in a brief and comprehensive manner.

In addition, an entire bulk of amendments was introduced to Article 1 of the Constitution. Thus, Article 1 was supplemented by a new Part of Article 2, which specifies (clarifies) the constitutional and legal status of the Republic as a state within the Russian Federation. The new version of Part 2 of Article 1 establishes the attributes of the Republic's statehood: "The Republic of Sakha (Yakutia) has its own territory, population, Constitution and legislation, the system of state bodies, as well as state symbols and national languages". The word "sovereignty" was deleted from Part 3 of Article 1. The amendments concerning Part 4, which was transformed into Part 5 are particularly worth noting: the word "its" was deleted from the phrase "its people" (that is, the people of the Republic). According to the Constitution of the Russian Federation, multi-ethnicity of Russia is the source of its power, therefore, the deletion of "its" from the text of the Constitution of the Republic is a significant clarification which confirms that this part of the Constitution of the Republic is made fully compliant with the Constitution of Russia.

Other amendments were also adopted to achieve the same goals - to bring certain provisions of the Constitution of the Republic into conformity with the federal Constitution. For instance, in connection with the change of the federal legislation concerning naming the titles 
of the highest official of a subject of the Russian Federation ${ }^{4}$, the amendments to rename the President of the Republic to the Head of the Republic were introduced to the Constitution of the Republic of Sakha (Yakutia). The initiators of these amendments (we should note that the initiative advanced by a group of 12 State Duma deputies and 11 members of the Federation Council was adopted rather quickly compared to other draft laws proposed by individual deputies or a group of deputies) considered the name of the post (the president), which was already well-established in the republics (in 13 out of 21), as superfluous and capable of creating certain obstacles to perceiving the post of the President of the Russian Federation as a unique one. Therefore, almost all the republics had to introduce amendments to the corresponding norms of their constitutional legislation.

\section{Conclusion}

Constitutional and legal development of the Republic of Sakha (Yakutia) as a part of the Russian Federation has been determined by many factors. The primary one is the existence of a single legal space in the Russian Federation with the supremacy of the Constitution of the Russian Federation and federal legislation. Accordingly, constitutional and legal development of the Republic is directly affected by the constitutional and legal development of Russia. For the period of 25 years since the adoption of the Constitution of the Russian Federation, Russia has come a long and complicated way, and this way has greatly influenced the constitutional and legal processes in the Republic of Sakha (Yakutia).

Over 26 years 10 chapters $^{5}$ of the republican Constitution out of 11 have been subjected to different amendments; about 20 Resolutions of the Constitutional Court of the Republic of

\footnotetext{
4 Two Federal Laws were adopted on the issue: FL of December $28^{\text {th }}, 2010$ No. 406-FA; and FL of February $3^{\text {rd }}, 2015$, No. 4-FA.

5 "Yakutskie Vedomosti", No. 7, April 26"th 1992. Amendments introduced by the Constitutional Court of the Republic of Sakha (Yakutia) on June $15^{\text {th }}, 2016,1651-3$, No. 859-V came in effect from the date of official publication (published on Official legislative information Internet-portal. Available at: http://www.pravo.gov.ru - June $26^{\text {th }}, 2016$.
}

Sakha (Yakutia) on the interpretation of various constitutional norms were adopted ${ }^{6}$. This indicates, therefore, that the Constitution of the Republic is a living and sought-after document which reacts to the needs and requirements of the changing social and political situation. All states and nations face the problems of changing the constitutional legislation. It is impossible to completely avoid amendments to the constitutions, as global experience shows that states and nations have to go through similar processes under any political system. Constitutional legislation may and should change. It should meet the needs of the society. When speaking of federative state subjects, the challenges of amending their constitutional acts are accompanied by the crucial problem of bringing them in accordance with the federal acts. It goes without saying that the need for adjusting the legislation of the subjects of the Russian Federation when the federal legislation is changed is absolutely reasonable. Representing the legislation of the entire state, federal legislation establishes the essential and fundamental grounds for further rule-making. At the same time, it is obvious that the legislation of the subjects does not merely follow the federal legislation, but rather enriches and fills its fundamental provisions with content. That is why the subjects' legislation could also affect the federal legislation directly or indirectly. In practice, however, with some rare exceptions, there is a one-way process. Making the subjects to bring their acts in compliance with those of their own and arbitrarily demanding the recognition of their supremacy, the federal center follows the principle "the law is bad, but this is the law". Meanwhile, it often does not take into account the existence of another principle, the principle of reasonableness and utility of law. As a rule, the subjects' law-making processes are based on the ideas of practical expediency and the need for solving an actual problem. Therefore, the conflict between the requirements of federal legislation and the actual needs and interests of the subjects of the Federation is quite real. At the same time, it must be admitted that at the federal level, establishment and formation

\footnotetext{
6 Available at: https://ks.sakha.gov.ru/postanovlenija2
} 
of the Constitution was often determined and is determined by the specific political goals and opinions, influenced by immediate needs. In addition, the contemporary Russian Federation has completely overtaken the decision-making process in the majority of spheres within its state jurisdiction through its federal bodies. Distribution of powers established by Articles 71, 72 and 73 of the Constitution of the Russian Federation implies that the subjects of the Federation seem to have considerable powers, including those within the residual competence. In reality, however, the Federation hardly leaves any significant issue for independent decision-making. A situation when it is possible to apply Part 6 of Article 76 of the Constitution of the Russian Federation "In the event of contradiction between the federal law and regulatory legal act of the Russian Federation subject, issued in accordance with Part 4 of the present Article, the regulatory legal act of the Russian Federation's subject remains in effect", is not considered even hypothetically. While the opposite situation, when the federal legislator intrudes into the sphere of the Federation subjects' jurisdiction, is quite admissible ${ }^{7}$. Unfortunately, this is an indicator of the Federation degradation. Moreover, to even greater regret, many issues of the Federation subjects' development are solved at the level of political elites and on the basis of personal agreements. There are numerous models of federative structure: constitutional,

\footnotetext{
7 In case a subject of the Federation has not adopted a law on an issue that falls within its competence, the federal legislator may exercise legal regulation in this area. See: Resolution of the Constitutional Court of the Russian Federation No. 15-P, of November $3^{\text {rd }}, 1997$.
}

contractual, symmetrical, ethnic, territorial, cooperative, dualistic, subsidiary, competing (competitive), etc., and we can endlessly argue about which model would be better for Russia. However, it should be admitted that all these models are effective under condition if subjective factors do not outbalance objective needs in building up the state mechanism. The existing Russian model - constitutional, asymmetric and ethnic-territorial - is quite acceptable and does not require substitution. Only approaches to its implementation need to be reconsidered. One could recollect the positive examples of the advanced legislation of the Federation subjects in the 1990s, when the latter could actually exercise the right to independent law-passing in the sphere of joint jurisdiction, should such necessity arise ${ }^{8}$. In addition, self-restraint of the federal center and suspension of its systemic interference into the subjects' jurisdictions is crucial for the successful constitutional and legal development of the Federation's subjects. The federal center should also take into consideration the fact that any constitution, including Constitutions of the subjects of the Federation, as the fundamental political and legislative document of any state or part of a state, is a long-term act and cannot and must not undergo changes introduced in order to satisfy an immediate political conjuncture.

\footnotetext{
8 Resolutions of the Constitutional Court of the Russian Federation of February 1, 1996 No. 3-P and of January 9, 1998 No. 1-P formulated the legal position according to which the absence of a corresponding federal law on joint jurisdiction does not prevent the subjects of the Federation from adopting their own normative acts, which follows from the nature of joint competence.
}

\section{References}

Bredikhin, A.L. (2014). Suverenitet kak politiko-pravovoi fenomen [Sovereignty as a Political and Legislative Phenomenon]. Moscow, Infra-M, 128 p.

Farukhshin, M.Kh. (2017). Institutsional'nye osnovy etnicheskikh federatsii [Institutional Foundations of Ethnic Federations]. In Politicheskie issledovaniia [Political Studies], 2, 103-117.

Ilyina, O.Yu. (2015). Federativnoe prostranstvo Rossii i polozhenie v nem sub"ekta RF [Federative Space of Russia and Position of the Russian Federation Subject in It]. In Konstitutsionnoe i municipal'noe pravo [Constitutional and Municipal Legislation], 3, 24-30.

Pastukhova, N.B. (2010). Gosudarstvennyi suverenitet: vchera i segodnia [State Sovereignty: Yesterday and Today]. Moscow, Aspekt Press, 301 p. 
Umnova, I.A. (2013). Konstitutsionnye osnovy sovremennogo rossiiskogo federalizma: model' i real'nost' [Constitutional Foundations of Modern Russian Federalism: Model and Reality]. In $K$ novoi modeli rossiiskogo federalizma [To the New Model of Russian Federalism], 65-89.

\title{
Конституционно-правовое развитие Республики Саха (Якутия) в постсоветский период
}

\author{
А.А. Степанова, А.И. Степанов, \\ С.С. Алексеева \\ Северо-Восточный федеральный университет \\ им. М.К. Аммосова \\ Российская Федеращия, Якутск
}

\begin{abstract}
Аннотация. В статье прослеживаются и анализируются современные тенденции развития российского федерализма и их влияние на конституционно-правовое развитие Республики Саха (Якутия) как субъекта Федерации. Дается подробная характеристика изменений конституционного законодательства республики. Целью исследования является определение степени влияния федерального центра на конституционно-правовое развитие республики. В ходе исследования использовались исторический, технико-юридический и сравнительно-правовой методы. В статье современное конституционно-правовое развитие республики разделено на два этапа: с 1990 по 2000 год и с 2000 года по настоящее время. Первый этап характеризуется относительной свободой республики в формировании своего конституционного пространства, включая государственно-территориальное устройство. Для следующего же этапа характерно последовательное почти полное ограничение ее конституционно-правовой самостоятельности. В современной России происходит довольно жесткое федеральное вмешательство в конституционно-правовое пространство субъектов Федерации, ограничивающее их свободу в определении механизмов взаимоотношений между органами государственной власти и установлении собственных государственно-правовых институтов. По мнению авторов, такое вмешательство оказывает негативное влияние на конституционно-правовое развитие Республики, и современной России, по меньшей мере, требуется самоограничение федеральной власти в сфере федеративных отношений и, как следствие, оптимизация конституционных механизмов разделения общефедеральных и региональных интересов.
\end{abstract}

Ключевые слова: республика, конституция, федерализм, суверенитет, изменения конституции, федеральное вмешательство.

Научная специальность: 24.00.00 - культурология. 